\title{
PELATIHAN HARDINESS SEBAGAI UPAYA PEMBENTUKAN KARAKTER TANGGUH (HARDINESS) DALAM MENGHADAPI PEMBELAJARAN JARAK JAUH DI MASA PANDEMI COVID-19
}

\author{
Muhammad Arsyad dan Sulistiyana \\ Program Studi Bimbingan dan Konseling, Fakultas Keguruan dan Ilmu Pendidikan, \\ Universitas Lambung Mangkurat \\ Email : arsyad.bk@ulm.ac.id
}

\begin{abstract}
ABSTRAK
Pada masa pandemic covid-19 siswa menghadapi pembelajaran jarak jauh. Berbagai permaslahan muncul terutama adanya penurunan prestasi, kebosanan hingga adanya ancaman siswa putus sekolah. Bedasarkan hal tersebut maka diperlukan suatu karakter yang dapat menguatkan siswa untuk tetap bersemangat dalam menuntut ilmu dimasa pandemic covid-19. Tujuan dilaksanakan kegiatan adalah untuk membentuk karakter tangguh pada siswa SMPN 27 Banjarmasin dalam menghadapi pembelajaran jarak jauh sehingga mampu lebih stabil dan kuat dalam menyesuaikan diri pada proses pembelajaran yang terdampak pandemic covid-19. Karakter tangguh hadir dengan membawa 3C, yaitu aspek dari hardiness yang berupa tantangan, control dan komitmen. Aspek tersebut mampu membuat siswa lebih kuat dan stabil dalam menghadapi tantangan pembelajaran dimasa pandemik. Lebih kuat dan bersemangat dalam mengejar cita-cita sehingga mampu meningkatkan kualitas sumber daya manusia yang akan menjadi penerus bangsa. Metode yang dilakukan dalam kegiatan ini adalah pelatihan yang menekankan pada keterampilan sehingga mampu membentuk karakter tangguh (hardiness). Ppelatihan ini dilaksanakan dalam tiga sesi selama dua hari dengan total waktu 6 jam. Hasil dari pelatihan ini siswa memiliki pemaham mengenai ketangguhan. Mampu membayangkan cita-cita dan menjadi bersemangat untuk mengikuti pembelajaran jarak jauh walaupun terdapat sejumlah kendala. Selain itu seluruh siswa merasa tertantang untuk melakukan pembelajarn jarak jauh untuk menghasilkan prestasi sebagai upaya untuk meraih cita-citanya.
\end{abstract}

Kata Kunci: Pelatihan, Ketanggunan, Hardiness, Covid-19

\section{PENDAHULUAN}

Pendidikan adalah pondasi sebuah bangsa dalam kemajuan peradaban. Pendidikan memiliki peran penting untuk membentuk generasi penerus yang akan menentukan kemajuan suatu bangsa. Hal ini sesuai dengan amanat dalam pembukaan UUD 1945, yaitu mencerdaskan kehidupan bangsa. Artinya peran penting pendidikan mengarah pada cita-cita bangsa yang tercantup pada UUD 1945. Berdasarkan hal tersebut, maka pendidikan di Indonesia diolah secara berjenjang sesuai tugas perkembangan peserta didik. Jenjang pendidikan wajib bagi warga Indonesia adalah: Sekolah Dasar, Sekolah Menengah Pertama dan Sekolah Menengah Atas. 
Pendidikan bagi tiap-tiap individu merupakan pengaruh dinamis dalam perkembangan jasmani, jiwa, intelek, perasaan sosial, susila, dan sebagainya (Chomaidi \& Salamah, 2018: 48). Individu yang mengikuti jenjang pendidikan diharapkan mampu membentuk individu yang cerdas dan berakhlak mulia. Artinya pendidikan tidak hanya membentuk individu pada ranah kognitif tetapi mencakup semua aspek termasuk social, emosi yang melahirkan karakter kepribadian yang berakhlak mulia.

Pada tahun 2020, dunia dilanda adnya pandemic covid-19 yang mengharuskan dunia pendidikan kembali harus menyesuaikan dengan situasi. Di Indonesia, jelas kehadiran Pandemi Covid-19 memberikan tantangan tersendiri. Hampir disemua daerah berdampak. Hal ini juga memunculkan adanya keputusan bersama empat menteri. Salah satu keputusan tersebut adalah membatasi aktivitas pembelajaran tatap muka di jenjang pendidikan terutama pada zona merah. Akibatnya pelaksanaan pembelajaran dilakukan dengan jarak jauh. Hal tersebut bertujuan untuk mengurai resiko penyebaran Covid-19 di lingkup satuan pendidikan.
Hadirnya sistem pembelajaran jarak jauh (PJJ) memiliki sejumlah dampak baik positif maupun negatif. Pembelajaran jarak jauh memberikan dampak positif yaitu mengefisienkan pembelajaran yang berbeda wilayah dengan jaringan internet. Namun hal ini juga berdampak negatif, Lani Diana Wijaya pada tanggal 1 Oktober 2020 menuliskan pada tempo.com mengenai dampak negative dan positif pembelajaran jarak jauh selama pandemic covid 19. Menurutnya ada enam dampak negative yang menjadi ancaman apabila pembelajaran jarak jauh terus dilaksanakan, yaitu, ancaman putus sekolah, penurunan capaian pembelajaran, adanya potensi anak menjadi korban kekerasan di rumah, keterbatasan gawai dan kuota internet sebagai fasilitas penunjang, anak beresiko kehilangan pembelajaran atau learning loss, dan anak menjadi kurang bersosialisasi.

Selain itu berdasarkan hasil pengabdian masyarakat yang dilakukan oleh Gunawan, dkk (2020) menyebutkan bahwa pembelajaran daring juga dinilai kurang efektif hal ini juga terkait dengan tersedianya sumber pembeljaran serta sarana dan prasaranan pembelajarang sistem online. Hal ini 
tentu akan berpengaruh terhadap daya juang dari siswa dibandingkan pada pembelajaran tatapmuka atau konvensional biasa. Hal ini akan sangat terihat perbedaan pembelajaran yang dilakukan secara tatapmuka dengan pembelajaran secara jarak jauh di masa pandemic covid-19 ini.

Berbagai kendala tersebut tentu sangat berpengaruh terhadap proses mencapai pencapaian tujuan dari pendidikan. Secara khusus di sekolah wilayah kota Banjarmasin juga terdampak. Salah satunya di SMPN 27 Banjarmasin. Tidak semua siswa mampu memiliki fasilitas pendukung dalam pembelajaran jarak jauh, sehingga hal tersebut menimbulkan perilaku malas bahkan memunculkan adanya penurunan pencapaian pembelajaran. Selain itu, hal ini juga berdampak bagi orangutan yang samasama bekerja sehingga kurangnya pengawasan anak di rumah juga menjadi kendala sehingga kurang pendampingan dalam proses belajar. Tingkat stress orangtua meningkat dan anak mudah mengalami kebosanan di rumah. Hal ini bagi guru merupakan suatu kendala yang cukup sulit untuk di atasi karena terkait keadaan sosial ekonomi keluarga.
Salah satu upaya yang juga dilakukan untuk mengatasi kecemasan pada masa pandemic covid-19 ini adalah dengan cybercounselling (Sulistiyana \& Sugianto, 2021). Hal ini karena cybercounseling merupakan sebuah strategi bimbingan dan konseling yang yang memberikan pelayanan konseling melalui jaringan internet. Akan tetapi walaupun hadirnya cybercounseling dapat membantu untuk mengurangi dampak dari kecemasan di masa pandemi. Namun perlu adanya menanamkan suatu sikap atau karakter yang kuat untuk mampu melewati tantangan pembelajaran jarak jauh dimasa pandemic ini, terutama bagi siswa-siswa sekolah menengah.

Berdasarkan hal tersebut maka perlu adanya suatu karakter kepribadian yang mampu secara terbuka menghadapi penyesuaian diri padi situasi baru dengan pembelajaran jarak jauh. Karakter yang dimaksud adalah karakter tangguh (hardiness). Karakter merupakan gaya kepribadian yang sering dikaitkan dengan ketangguhan atau hardiness. Santrock (2002:145) dalam Adrianto, 2019:125 mengatakan bahwa ketangguhan atau hardiness adalah gaya kepribadian yang dikarakterisitikkan oleh suatu 
komitmen, pengendalian, dan persepsi terhadap masalah-masalah sebagai tantangan. Dengan demikian, hardiess mengandung arti suatu konstelasi karakteristik kepribadian yang menyebabkan individu lebih kuat, tahan, stabil, dan optimis dalam menghadapi stres dan mengurangi efek negatif yang dihadapi (Adrianto, 2019:126).

Konsep tentang ketangguhan atau hardiness awalnya dikemukakan oleh Kobasa sebagai suatu variabel yang ada dalam diri individu dalam menerima atau menghadapi sesuatu. Maddi \& Kobasa mengungkapkan orang yang memiliki hardiness memiliki pengertian akan hidup dan komitmen yang tinggi akan pekerjaan, memiliki kontrol akan perasaan yang baik dan terbuka akan berbagai kesempatan dan tantangan dalam hidup (Adrianto, 2019:125). Konsep hardiness merupakan konsep 3C yang merupakan pendekatan eksistensial humanistic yang mengarah pada tiga aspek hardiness yang dapat membentuk karakter tangguh pada siswa, terutama dalam menghadapi tantangan pembelajaran jarak jauh di masa pandemic covid-19. Tiga aspek tersebut yaitu, Komitmen, Kontrol dan Tantangan (Arsyad, 2015).
Noltemeyer \& Abdollahi (2016) menemukan bahwa model $3 \mathrm{C}$ Hardiness tersebut memberikan bukti bahwa komitmen, kontrol, dan tantangan memiliki hubungan positif terhadap sekolah dengan prestasi akademik. Berdasarkan hasil penelitian Abdollahi, dkk (2020) menemukan bahwa akademik hardiness dapat bertindak sebagai mediator antara rasa memiliki sekolah dan stress akademik. Artinya bahwa akademik hardiness dapat menjadi pertimbangan utama bagi semua sekolah untuk mengurangi stress akademik yang dialami siswanya.

Berdasarkan hal tersebut maka karakter tangguh (hardiness) memungkinkan dapat membantu siswa untuk lebih mudah menyesuaikan diri dalam menghadapi pembelajaran jarak jauh dimasa pandemik covid-19. Artinya harapan hadirnya karakter tangguh (Hardiness) dalam membantu siswa lebih siap dengan situasi baru dan tetap mempertahankan pencapaian akademik di sekolah walaupun di masa pandemic covid-19. Berlandaskan hal tersebut maka, Program Studi Bimbingan dan Konseling FKIP Universitas Lambung Mangkurat menginisiasi mengadakan sebuah pengabdian kepada masyarakat dengan 
melakukan "Upaya Pembentukan Karkater Tangguh (Hardiness) dalam Menghadapi Pembelajaran Jarak Jauh di Masa Pandemi Covid-19 pada Siswa SMPN 27 Banjarmasin".

\section{METODE PELAKSANAAN}

Metode yang dilakukan dalam kegiatan ini adalah pelatihan yang menekankan pada keterampilan sehingga mampu membentuk karakter tangguh (hardiness). Pelatihan ini dilaksanakan dalam tiga sesi selama dua hari dengan total waktu 6 jam. Adapun 5 langkah yang dilakukan dalam kegiatan pelatihan ini adalah perencanaa, persiapan, pelaksanaan, evaluasi dan pelaporan.

Pada pelaksanaan pengabdian masyarakat ini yang menjadi objek adalah 10 orang siswa SMPN 27 yang terdampak Pandemi Covid-19. Dalam hal ini SMPN 27 telah melaksanakan pembelajaran jarak jauh.

\section{HASIL DAN PEMBAHASAN}

Secara umum pelaksanaan pelatihan hardiness dilakukan sebanyak 3 sesi pelatihan selama dua hari dengan tahapan kegiatan yaitu: registrasi, ceramah, video, sharing pengalaman, dan tanya jawab. Selain itu juga ditambahkan pengisian lembar kerja yang juga bagian dari evaluasi proses. Pelaksanaan pelatihan hardiness ini dilakukan oleh seorang narasumber/fasilitator dari dosen program studi bimbingan dan konseling. Pada kegiatan pelatihan hardiness ini dihadiri oleh 10 orang siswa. Awalnya siswa agak canggung dalam mengikuti kegiatan karena telah lama melaksanakan pembelajaran jarak jauh. Namun setelah diberikan pengalaman dengan menggunakan permainan, siswa mulai antusias mengikuti kegiatan dan mengerjakan semua yang diinstruksikan oleh fasilitator. Siswa melaksanakan diberikan sebuat simulasi dari games dan merefleksikan sebuah pengalaman melalui video yang mengarahkan pada 3 komponen aspek dari hardiness.

Ketangguhan (Hardiness) telah dikonseptualisasikan sebagai kombinasi dari tiga sikap (3C) komitmen, kontrol, dan tantangan (Khoshaba dan Maddi, 2005). Komitmen (vs keterasingan) melambangkan orang-orang yang berkomitmen dan merasa sangat terlibat dalam kegiatan hidup mereka. Control (vs ketidakberdayaan) mencerminkan keinginan untuk terus memiliki pengaruh pada hasil yang terjadi di 
sekitar, tidak peduli seberapa sulit hal tersebut terjadi. Challenge (vs keamanan) melambangkan harapan bahwa hidup berubah-ubah, bahwa perubahan akan merangsang pengembangan pribadi, dan bahwa situasi yang tidak berpotensi stres yang dinilai sebagai menarik dan merangsang daripada mengancam (Maddi, 2006).

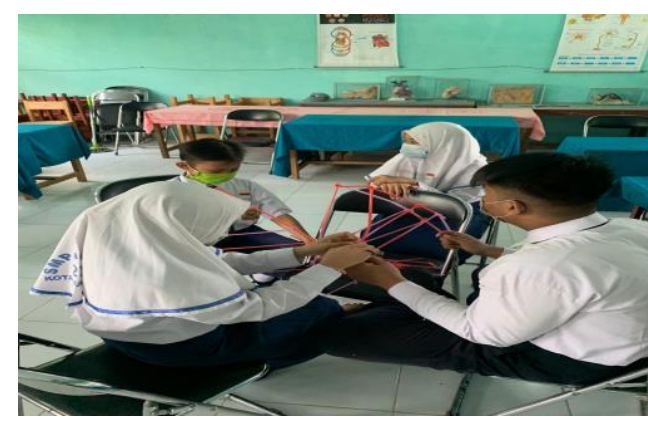

\section{Gambar 1. Proses permainan}

Sesi pelatihan terdiri dari tiga aspek yang membangun dari teori Hardiness (Maddi, 2006). Aspek tersebut yaitu :

1. Tantangan (challenge)

Merupakan keyakinan bahwa perubahan merupakan suatu bagian yang normal dari kehidupan. Oleh karena itu, perubahan dipandang sebagai suatu kesempatan untuk tumbuh dan berkembang dan bukan sebagai hal yang menekan. Sikap yang mencerminkan tantangan seharusnya menjembatani prestasi akademik dengan memberikan kesempatan siswa untuk menilai situasi yang menekan menjadi menarik dan merangsang daripada mengancam. Ini seharusnya meningkatkan kemungkinan siswa menerima kesulitan yang berhubungan dengan memenuhi persyaratan akademik dan terlibat dalam proses bekerja mencapai tujuan, sehingga memudahkan proses positif pertumbuhan dengan orientasi berbasis pembelajaran.

\section{Kontrol (control)}

Melibatkan keyakinan bahwa individu mampu mempengaruhi kejadian- kejadian dalam hidupnya. Orang-orang yang memiliki ciri ini lebih cenderung meramalkan peristiwa yang penuh stres sehingga dapat mengurangi keterbukaan mereka pada situasi yang menghasilkan kegelisahan. Selanjutnya, persepsi mereka atas keadaan terkendali dan mengarahkan "hal-hal internal" untuk menggunakan strategi penanggulangan yang proaktif. Siswa yang tinggi dalam kontrol seharusnya dapat mengelola studi mereka; misalnya, menunjukkan manajemen waktu yang baik, memprioritaskan kegiatan-kegiatan yang dianggap paling berkontribusi untuk keberhasilan akademis, dan berusaha dan melakukakan pengendalian emosi dengan regulasi diri 
mengambil tanggung jawab untuk belajar dan pengembangan pribadi.

3. Komitmen (commitment)

Mencerminkan sejauhmana seorang individu terlibat dalam apapun yang sedang ia lakukan. Orang yang berkomitmen memiliki suatu pemahaman akan tujuan dan tidak menyerah di bawah tekanan karena mereka cenderung menginvestasikan diri mereka sendiri dalam situasi tersebut. Pengaruh moderating komitmen pada kinerja akademik dapat ditunjukkan oleh siswa menjadi sangat terlibat dalam studi mereka, melihat ini sebagai cara terbaik untuk mengubah apa pun yang mereka alami menjadi sesuatu yang tampaknya menarik, berharga, dan penting. Sikap seperti membuat pengorbanan pribadi untuk unggul secara akademis untuk memfasilitasi kerajinan dan kesediaan untuk mengeluarkan waktu dan tenaga ekstra untuk memenuhi tujuan akademis.

Berdasarkan hasil evaluasi yang dilakukan kepada siswa didapatkan hasil bahwa siswa mampu memahami materi yang disampaikan oleh fasilitator/narasumber. Selain itu, peserta merasa terbantu dengan adanya kegiatan pelatihan tersebut untuk menghadapi proses pembelajaran jarak jauh. Setelah pelatihan siswa merasa tertantang untuk belajar. Hal ini karena siswa sudah mampu menunjukkan tujuan dan cita-cita yang ingin di capai. Mereka juga sudah cukup mampu memahami hakikat waktu sehingga meraka mulai menyadari keterkaitan waktu dengan keinginannya untuk mencapai cita-cita. Hal ini juga berpotensi membuat siswa memiliki komitmen untuk meraih apa yang dicita-citakan. Artinya dengan pelatihan tersebut, siswa menunjukkan adanya aspek-aspek ketangguhan dalam menghadapi pembelajaran jarak jauh.

Selain itu, siswa juga memberikan peniaian yang baik pada fasilitas dan pelaksanaan pelatihan. Siswa juga menilai alokasi waktu yang dilaksanakan sudah sesuai. Variasi permainan dalam metode yang digunakan menarik dan membuat siswa cukup tertantang.

Pelaksanaan pelatihan ini memberikan bekal kepada siswa untuk tetap tanggung dalam menghadapi perubahan situasi akibat pandemi covid19 yang mengharuskan mereka melaksanakan pembelajaran jarak jauh. Siswa menyadari bahwa ada tantangan yang harus mereka hadapi. Kontrol dan 
komitmen dalam menjalani aktifitas belajar mengarahkan mereka pada tujuan yang ingin di raih, yaitu citacitanya.

Ketangguhan akademik merupakan ciri kepribadian yang dapat membedakan siswa yang menghadirkan pekerjaan yang menantang pada tujuan akademis dari orang lain yang bersedia untuk mengejar jenis tantangan. Sikap tangguh yang kuat pada siswa dapat memfasilitasi mengubah tekanan untuk keuntungan, yang berkembang sedemikian kriteria kinerja yang ditingkatkan karena kreativitas, kebijaksanaan, dan pemenuhan, dan memelihara atau meningkatkan kesehatan fisik dan mental (Maddi, 2006). Jika sikap yang tangguh sangat kuat, individu akan menunjukkan pola tindakan untuk mengatasi situasi stres (misalnya, pemeriksaan, pertemuan saat deadline pekerjaan, menyelesaikan proyek penelitian akhir-tahun) dengan menghadapinya, dan berusaha untuk mengubahnya dari potensi bencana menjadi peluang untuk diri (Khoshaba \& Maddi, 2005).

Menurut Maddi dan Khoshaba (2001), individu tangguh membangun makna dalam hidup mereka dengan mengakui bahwa (a) semua yang mereka lakukan merupakan bentuk dari sebuah keputusan, (b) keputusan selalu melibatkan dorongan menuju masa depan, dan (c) pemilihan masa depan memperluas makna, sedangkan memilih berkontraksi dengan masa sebelumnya. Meskipun bermakna positif dan berpeluang, memlih masa depan menimbulkan kecemasan atas ketidakpastian pada hal-hal yang belum pernah dialami. Untuk menerima kecemasan dan mendorong maju dengan memilih masa depan tetap dibutuhkan keberanian yang termanisfestasi dari teori eksistensialis. Mensubtitusikan keberanian dengan hardiness mengedapankan presisi untuk merumuskan eksistensial dengan menekankan tiga kepercayaan yang saling terkait mengenai interaksi seseorang dengan dunia: Komitmen, kontrol, dan tantangan.

Kobasa menjelaskan hardiness dalam konteks pendidikan menggunakan istilah academic hardiness (benishek \& Lopez, 2001). Teori hardiness yang dikembangkan oleh kobasa memberikan kerangka penting guna memahami hal yang membuat siswa memiliki keinginan yang lebih untuk terikat dengan berbagai tantangan akademis. Hardines 
dapat memainkan peran yang positif dalam kehidupan siswa (Cress dan Lampman, 2007). Hardinesss merupakan faktor kepribadian yang diyakini sebagai faktor internal dari berbagai faktor yang mempengaruhi prestasi akademis (Maddi, dkk., 2012).

\section{KESIMPULAN}

Berdasarkan

pelaksanaan

pelatihan hardiness tersebut dapat simpulkan berjalan cukup baik dan lancar. Selain itu juga memberikan pengetahuan serta berpotensi membentuk karakter tangguh siswa dalam menghadapi pembelajaran jarak jauhdimasa pandemi Covid-19. Sikap tanggung dapat mengurangi berbagai kendala dalam pembelajaran dan mampu memberikan pandangan positif terhadap studi.

Pelaksanaan pelatihan hardiness ini sebagai upaya untuk mengembangkan karakter tanggung pada siswa dalam menghadapi pembelajaran jarak jauh pada masa pandemi covid-19. Siswa perlu diberikan pelatihan-peatihan yang mampu membuatnya tidak mengalami berbagai permasalahan selama pembelajaran jarah jauh seperti kebosanan hingga kemalasan dalam mengikuti kegiatan pembelaran karena tidak ada kontrol yang memberikan pengawasan. Artinya kegiatan seperti ini akan menjadi saran yang positif bagi guru untuk tetap menjaga sikap mental siswa dalam mengikuti pembelajaran jarah jauh dimasa pandemi.

\section{DAFTAR PUSTAKA}

Benishek, L. A. \& Lopez, F. G. (2001). Development and Initial Validation of a Measure of Academic Hardiness. Journal of Career Assessment 2001 9: 333.

http://jca.sagepub.com/content/ 9/4/333

Benishek, L. A., Feldman, J. M., Wolf Shipon, R. W., Mecham, S. D., $\&$ and Lopez, F. G. (2005). Development and Evaluation of the Revised Academic Hardiness Scale. Journal of Career Assessment, vol. 13. Sage Publication.

Bonanno, G. (2004). Loss, trauma, and human resilience: Have we underestimated the human capacity to thrive after extremely aversive events? American Psychologist, 51, 72-82.

Cain, D. J., Seeman. J. (2002). Humanistic psychotherapies, handbook of research and practice. Washington, DC: American Psychological Association.

Cole, M. S., Field, H. S., \& Harris, S. G. (2004). Student Learning Motivation and Psychological Hardiness: Interactive Effects 
on Students' Reactions to a Management Class. Academy of Management Learning and Education, Vol. 3, No. 1, 6485.

Corey, G. (2005). Teori dan praktek dari konseling dan psikoterapi. Terjemahan oleh E. Koeswara. Jakarta: ERESCO.

Cress, V. C., Lampman, C. (2007). Hardiness, stress, and healthpromoting behaviors among college students. Psychological Journal Of Undergraduate Research. 12, 18-23

Kobasa, S. C. (1979). "Stressful life events, personality, and health - Inquiry into hardiness". Journal of Personality and Social Psychology 37 (1): 1$11 . \quad$ doi:10.1037/00223514.37.1.1

Gunawan Aam, dkk. (2020). Efektifitas dan Pengalaman Pembelajran Daring di Fakultas Pertanian Universitas Islam Kalimantan Muhammad Arsyad Al Banjari Banjarmasin. Jurnal Pengabdian Al-Ikhlas. Volume 6 Nomor 2, 220-227, Desember 2020. ISSN:24610992.

http://dx.doi.org/10.31602/jpai uniska.v6i2. https://ojs.uniskabjm.ac.id/index.php/AIJP/issue /view/390

Maddi , S.R. (2004). Hardiness: An Operationalization of Existential Courage. Journal of Humanistic Psychology 2004 44: $279 \quad$ DOI: 10.1177/0022167804266101. http://jhp.sagepub.com/content/ 44/3/279
Maddi , S.R. (2006). Hardiness: the courage to grow from stresses. Journal of Positive Psychology, 1, 160-168.

Maddi, S. R., Harvey, R. H., Khoshaba, D. M., Fazel, M., \& Resurreccion, N. (2012). The Relationship of Hardiness and Some Other Relevant Variables to College

Performance .Journal of Humanistic Psychology. DOI: 10.1177/0022167811422497. http://jhp.sagepub.com/content/ $\underline{52 / 2 / 190}$

Maddi, S. R., \& Khoshaba, D. M. (2001). Personal views survey (3rd ed., rev.). Newport Beach, CA: The Hardiness Institute.

Maddi , S.R. \& Khoshaba, D. M. (2005). Resilience at work : how to succeed no matter what life throws at you. USA: AMACOM.

Maddi, S. R., Khoshaba, D. M., Persico, M., Lu, J., Harvey, R., \& Bleecker, F. (2002). The personality construct of hardiness, II: Relationships with comprehensive tests of personality and psychopathology. Journal of Research in Personality, 36, 72-85.

Sheard, M. (2009). Hardiness commitment, gender, and age differentiate university academic performance. British Journal of Educational Psychology, 79, 189-204. www.bpsjournals.co.uk

Sheard, M \& Golby, J. (2007). Hardiness and undergraduate academic study: The 
\begin{tabular}{l} 
moderating role $\quad$ of \\
commitment. Personality and \\
Individual Differences 43579 \\
588. \\
www.sciencedirect.com/science \\
\hline larticle/pii/S019188690700024 \\
$\underline{4}$
\end{tabular}

Smet, B. (1994). Psikologi Kesehatan. Jakarta: PT. Gramedia Widiasarana Indonesia.

Sulistiyana \& Sugianto, Akhmad. (2021). Bimbingan Teknis PenerapanCybercounseling Mengatasi Kecemasalan Remaja pada Tatanan New
Normal Bagi Konselor Sebaya di Pusat Informasi Konseling (PIK-R) Banjarmasin. Jurnal Pengabdian Al-Ikhlas. Volume 6 Nomor 3, 352-364, April 2021. ISSN:2461-0992. http://dx.doi.org/10.31602/jpai uniska.v6i3. https://ojs.uniskabjm.ac.id/index.php/AIJP/issue /view/408

Weiner, I. B. (2003). Handbook of psychology, clinical psychology. John wiley \& Sons: USA 